\title{
Antalya ve Mersin Yöresi Kızılçam Meşcereleri için Ağaç Hacim Tabloları
}

\author{
Aydın KAHRIMAN*1, Turan SÖNMEZ ${ }^{2}$, Abdurrahman ŞAHİN ${ }^{1}$ \\ ${ }^{1}$ Artvin Çoruh University, Faculty of Forestry, 08000, Artvin, Turkey \\ ${ }^{2}$ Bursa Technical University, Faculty of Forestry, 16330, Artvin, Turkey \\ *Sorumlu yazar: kaydin61@hotmail.com
}

Geliş Tarihi: 10.06.2016

Kabul Tarihi:13.12.2016

Özet: Bu çalışmada, Antalya ve Mersin yörelerinde yer alan saf ve doğal Kızılçam (Pinus brutia Ten.) meşcereleri için tek, bonitete dayalı tek ve çift girişli ağaç hacim tablolarının düzenlenmesi amaçlanmıştır. Bu amaçla 486 örnek ağaç ve bu ağaçlardan türetilen 6033 adet veri kullanılarak, ağaç hacim denklemleri geliştirilmiştir. Seçilen en uygun hacim fonksiyonlarının düzeltilmiş belirtme katsayısı $\left(R_{d \ddot{z} z .}^{2}\right)$, tahminin standart hatası $\left(\mathrm{S}_{\mathrm{y} . \mathrm{x}}\right)$, ortalama mutlak hata yüzdesi $(\% \mathrm{OMH})$ ve toplam hata yüzdesi $(\% \mathrm{TH})$ değerleri sırasıyla; tek girişli için $0.975,52.84$, -0.457 ve 9.756; I. bonitet sınıfı tek girişli için $0.978,44.84,-0.438$ ve 9.849; II. bonitet sınıfı tek girişli için $0.976,54.44,-0.464$ ve 9.501; III. bonitet sınıfı tek girişli için $0.969,52.96,-0.452$ ve 9.256 ve çift girişli için ise $0.992,41.26,0.210$ ve 5.038 olarak hesaplanmıştır. Tek girişli ağaç hacim tablosu değeri, I. (\%-6.32) ve II. bonitet sınıflarında (\%-0.45) bonitete dayalı tek girişli ağaç hacim modelleri değerinden düşük, III. bonitet sınıfında ise daha büyük değerler (\%4.28) vermektedir. Çalışma kapsamında düzenlenen tek, bonitete dayalı tek ve çift girişli hacim tablolarının, bağımsız bir veri grubu ile Antalya ve Mersin ilerindeki Kızılçam meşcerelerine uygunluğu test edilmiş ve her bir hacim denkleminin de meşcerelere uygun olduğu ( $\mathrm{p}>0.05)$ sonucuna varılmıştır.

Anahtar Kelimeler: Kızılçam, Tek, bonitet dayalı tek ve çift girişli ağaç hacim tabloları, Bonitet, Antalya, Mersin

Tree Volume Tables for Calabrian Pine in Antalya and Mersin Region

Abstract: In this study, it is proposed to construct single, single based on site index and double entry tree volume equations for the pure Calabrian Pine stands (Pinus brutia Ten.) within the border of Antalya and Mersin Regional Forest Directorates, Turkey. Tree volume equations were developed using totally 486 sample trees and 6083 data obtained from these trees. The coefficient of determination (adj- $\mathrm{R}^{2}$ ), total percent error (PE), and mean absolute percentage error (MAPE) were 0.975, 52.84, -0.457 and 9.756 for single tree; $0.978,44.84,-0.438$ and 9.849 for single tree of the first site index class; $0.976,54.44,-0.464$ and 9.501for single tree of the second site index class; 0.969, 52.96, -0.452 and 9.256 for single tree of the third site index class, and 0.992, 41.26, 0.210 and 5.038 for double-entry tree volume equations, respectively. The first (\%6.32) and the second $(\% 0.45)$ site index values overestimated single-entry tree table values whereas the third site index values (\%-4.28) underestimated the single-entry tree table values. The best fitted single, single based on site index and double entry tree volume equations were tested with independent data set for Calabrian Pine stands within the border of Antalya and Mersin Regional Forest Directorates, and concluded that these equations can be used for these stands at the 0.05 significant level.

Keywords: Calabrian pine, Single, Single Based on Site Index and Double-Entry Tree Volume Tables, Site index, Antalya, Mersin

\section{Giriş}

Kızılçam (Pinus brutia Ten.), yayılış alanı, artım ve büyüme özellikleri, yarattı̆̆1 ekonomik değer dolayısıyla Türkiye'nin en önemli asli orman ağacı türlerinden biridir. Türkiye'de Akdeniz, Ege ve Marmara bölgelerinde geniş alanlar boyunca yayılmakta olup; Karadeniz bölgesinde ise Akdeniz iklimi özellikleri gösteren bölgelerde küçük topluluklar halinde görülebilmektedir (Anşin, 1994). Kızılçam (Pinus brutia Ten.), dünya üzerinde kuzey yarım kürede yaklaşık $32^{\circ}-45^{\circ}$ kuzey enlemleri ile $15^{\circ}-45^{\circ}$ doğu boylamları arasında kalan oldukça geniş bir bölgede doğal yayılış göstermektedir (Kayacık, 1965). Genel coğrafi yayılışı Doğu Akdeniz Havzası ve özellikle Türkiye topraklarıdır. Bu yayılışında batıda Kalabriya yarımadası, doğuda Irak'ın kuzeyine, kuzeyde Kırım ve güney de ise Filistin'e kadar yayılış göstermektedir (Asmaz, 1993). Bu sinırlarda birincil olarak Türkiye ve Doğu Yunanistan'da ve ikincil olarak da Kırım yarımadası, Kafkasya sahilleri, Gürcistan, 
Azerbaycan, Kuzeybatı İran, Kuzey Irak, Bat1 Suriye, Lübnan, Kibris ve Girit adasında yayılış göstermektedir. Kızılçam, bu bölgelerde Akdeniz iklimi özelliği olan yörelerde ve özellikle deniz kıyılarında yayılış göstermektedir (Davis, 1982; Pantelas, 1986).

Ormanın ana ürünü olan ve işletme sermayesinin büyük bir bölümünü oluşturan ağaç serveti, bir orman işletmesinin temel girdisi ve orman işletmesinin var oluşunu ortaya koyan temel öğedir (Yeşil, 1992; Yavuz, 1999; Kapucu, 2004). Meşcere modellerinin oluşturulmasında kullanılan meșcere hacminin doğru bir șekilde hesaplanması gerekmektedir. $\mathrm{Bu}$ amaçla meşcerelerdeki ağaçların hacimleri doğru bir şekilde tahmin edilmelidir. Tüm ağaç gövdeleri silindir, paraboloit, koni ve nayloit gibi bilinen geometrik şekillere tam olarak benzemediğinden analitik yöntemlerle ağaç hacmini doğrudan hesaplamak mümkün olmamaktadır. Buna karşın ağaç hacmini belirli bir hata miktarı ile tahmin eden pek çok yöntem geliştirilmiştir. Bunlardan en çok kullanılanı "Ağaç Hacim Tabloları" yöntemidir (Yavuz ve Sakıc1, 2002).

Ağaç hacim tabloları, dikili bir ağacın göğüs çap1, göğüs çap1-boy veya göğüs çap1boy-şekil katsayısı gibi değişkenlere göre, kalın odun hacmini ya da ticari hacmini veren tablolardır (Kalıpsız, 1999). Ağaç hacim tablolarının düzenlenmesinde temel amaç; ağaçların göğüs çapı ve boyu gibi kolay ölçülebilen değişkenleri ile hacim arasındaki ilişkinin belirlenmesi ve bu ilişkiye bağl1 olarak ağaç hacminin tahmin edilmesidir.

Ülkemizde Kızılçam ağaç türü için ilk ağaç hacim tablosu, Alemdağ (1962) tarafindan 361 adet ağaç verisi kullanılarak Akdeniz Bölgesi ve Güney Ege'de (Adana, Mersin, Antalya, Muğla, Denizli, Isparta) düzenlenmiştir. Kızılçam için genel hacim tablosu ise Sun ve ark., (1978) tarafindan 1160 örnek ağaç verisi ile düzenlenmiştir. Bunlardan farklı olarak, Usta (1991) tarafından Antalya, Muğla, Adana, Maraş illerinde 289 örnek ağaç verisi, Çatal (2009) tarafindan Burdur, Isparta, Konya, Afyonkarahisar, Muğla, Denizli, Antalya ve Mersin illerinde 892 örnek ağaç (72 örnek ağaçtan türetilen veri) verisi ve Kahriman ve ark. (2016) tarafindan Antalya ve Mersin illerinde 6033 örnek ağaç (486 örnek ağaçtan türetilen veri) verisi kullanılarak bölgesel, Özer ve Uğurlu (1977) tarafından AntalyaBük Araştırma ormanında 251 örnek ağaç verisi ve Carus ve Su (2014) tarafindan da Antalya-Korkuteli'nde 325 örnek ağaç (50 örnek ağaçtan türetilen veri) verisi kullanılarak yöresel ağaç hacim tabloları düzenlenmiştir. Ayrıca bazı araştırmacılar tarafından uyumlu gövde profili denklemleri ile Kızılçam için gövde hacmi ortaya konulmuştur. Brooks ve ark. (2008), Mut ve Elmalı yörelerinde Kızılçam için toplam 359 adet örnek ağaç verisi kullanılarak Max ve Burkhart (1976) tarafından geliştirilmiş segmented polinomiyal gövde çap1 denklemleri ile uyumlu gövde hacmi ve gövde çapı denklemleri geliştirmiştir. Özçelik ve Brooks (2012), Isparta Orman Bölge Müdürlüğünden elde ettiği 248 adet Kızılçam örnek ağaç verisi ile Clark ve ark. (1991) ve Max ve Burkhart (1976)'in segmented polinomiyal gövde çapı denklemlerini kullanarak uyumlu gövde hacim modelleri geliştirmiştir. Kumaş ve Kahriman (2016) tarafından Antalya yöresi Kızılçam meşcereleri için Demaerschalk (1972) tarafından geliştirilen gövde hacim denklemi ile çift girişli ağaç hacim denklemi geliş̧irilmiştir.

Ülkemizde asli ağaç türlerimizin hemen hemen hepsi için yöresel, bölgesel veya genel ağaç hacim tabloları bulunmakta ve Orman Amenajman Planlarında servet ve artım hesabı için bu tablolardan yararlanılmaktadır. Homojen yetişme ortamı ya da meşcere sıklık koşullarına sahip alanlar için bir hacim tablosu, toprak ve topoğrafik yapı değişiyorsa, her bir yetişme ortamı için ayrı birer hacim tablosunun düzenlenmesi önerilmektedir (Loetsch ve ark., 1973; Şentürk, 1997). Bu nedenle, günümüzde meşcere tipleri tanımlamasının yetişme ortamı verim gücüne (bonitete) dayalı olarak yapılmas1 söz konusudur. Bu durumda ağaç türlerimiz için mevcut olan ağaç hacim tablolarının da güncellenmesi ve hatta pratik olması açısından bonitete dayalı ağaç hacim tablolarının oluşturması gerekecektir ve henüz hiçbir ağaç türümüz için bonitete dayalı ağaç hacim tablosu düzenlenmemiştir. $\mathrm{Bu}$ sebeple, ülkemizde en geniş yayılış alanına sahip, hızlı gelişen türlerden olan ve 
ekonomik değeri yüksek olan Kızılçamda bu eksikliğin giderilmesi düşünülmüştür.

$\mathrm{Bu}$ çalışmada, Antalya ve Mersin yörelerinde yer alan saf ve doğal Kızılçam meşcereleri için tek, bonitet dayalı tek ve çift girişli ağaç hacim tablolarının düzenlenmesi ve elde edilen sonuçların daha önce düzenlenmiş olan ağaç hacim tabloları ile karşılaştırılması amaçlanmıştır.

\section{Materyal ve Metot}

Orman Genel Müdürlüğünün 2015 y1l1 orman envanterine göre ülkemizin toplam ormanlık alanı 22.342.935 ha olup (ülke yüzölçümünün $\% \quad 28,6$ 's1), bu alanın 5.610.215 ha'llk kısmında (ülke ormanlık alanının \%25.11'i) Kızılçam yayılış göstermektedir (Şekil 1). Kızılçam'ın yayılış gösterdiği alanların 3.451.269 ha' lık kısmı (\% 61.52) normal koru ve geriye kalan 2.158.946 ha'lık k1smı (\% 38.48) ise bozuk orman vasfindadır (Anonim, 2015). Antalya Orman Bölge Müdürlüğü'nün yüzölçümü olan 2.061.764 ha alanın yaklaşık \% 55.59'u $(1.146 .062$ ha) ormanlık alanlardan oluşmaktadır. Mersin Orman Bölge
Müdürlügü’nün yüzölçümü 1.563 .068 ha olup, bu alanın 840.470 ha'llk k1smı (\% 53.77) ormanlık alanlardan oluşmaktadır. Antalya ilinde 403.844 ha ve Mersin ilinde 357.352 ha olmak üzere çalışma alanındaki Kızılçam meşcerelerinin toplam kapladığ alan 761.196 ha'dır (Anonim, 2015).

Çalışma alanı Antalya ve Mersin Antalya Orman Bölge Müdürlükleri sinırları içerisindeki saf ve doğal yetişmiş Kızılçam meşcereleridir (Şekil 1). Araştırmaya konu olan Antalya ve Mersin illeri Türkiye'nin güney ve güneybatısinda (Orta ve Bat1 Akdeniz Bölgesi) yer almakta olup, $33^{\circ}-35^{\circ}$ doğu boylamları ile $36^{\circ}-37^{\circ}$ kuzey enlemleri arasindadir. Antalya ve Mersin illerinin güneyinde Akdeniz, kuzeyinde Burdur, Isparta, Konya, Karaman ve Niğde illeri, doğusunda Adana ve batısında ise Muğla yer almaktadır. Çalışma alanı olan Antalya ve Mersin illeri Akdeniz ikliminin özelliklerini taşır. Yazları sıcak ve kurak, kışları 1lık ve yağışlı geçer. Yıllık ortalama yağış Antalya ili için yağ 1 $1069,8 \mathrm{~kg} / \mathrm{m}^{2}$ ve Mersin ili için ise $585,4 \mathrm{~kg} / \mathrm{m}^{2}$ dir.

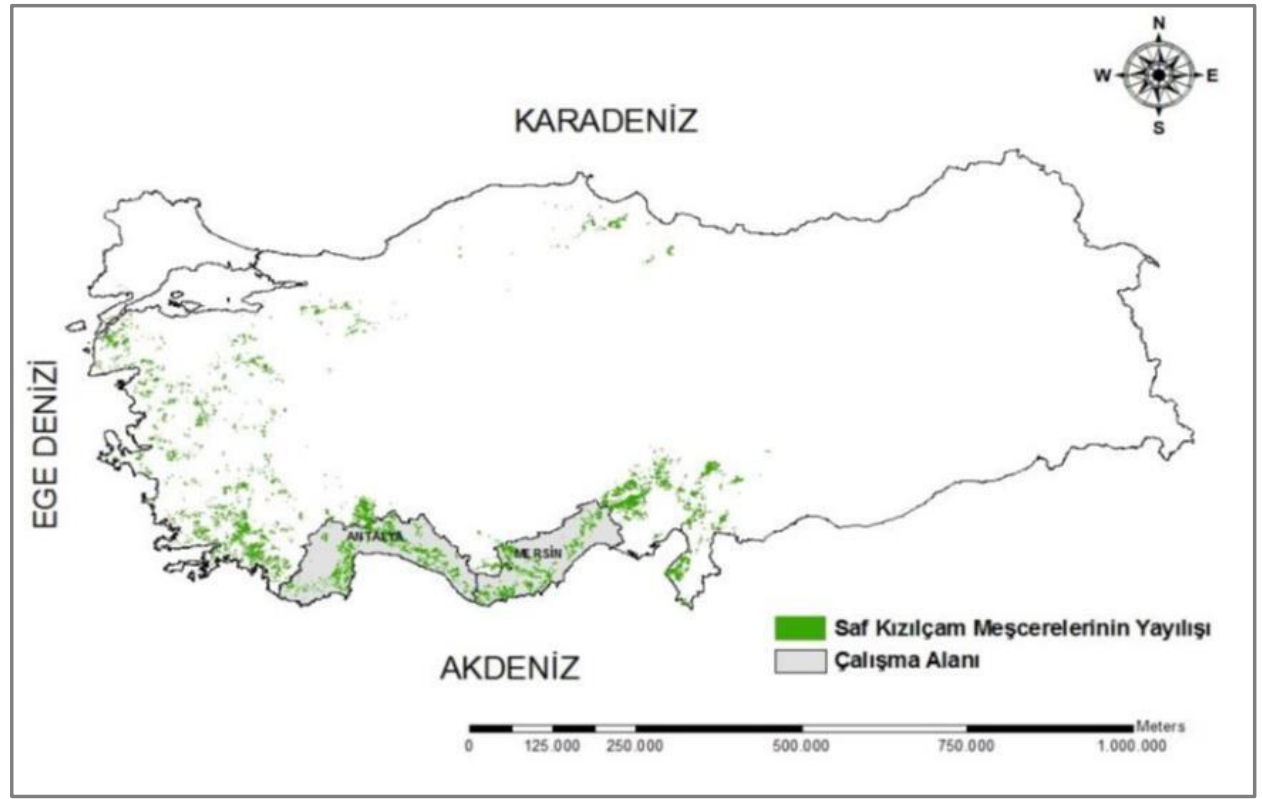

Şekil 1. Saf Kızılçam meşcerelerinin Türkiye'deki yayıllışı ve çalışma alanı

$\mathrm{Bu}$ çalışmada, araştırma materyali olarak "Antalya ve Mersin Yöresi Saf Kızılçam Meşcerelerinde Hasılat Araştırmaları" adlı ve "112O808" nolu TÜBİTAK Projesi verileri kullanılmıştır. $\mathrm{Bu}$ bağlamda, Antalya ve
Mersin Orman Bölge Müdürlükleri sınırları içerisinde yer alan eşityaşlı ve saf Kızılçam (Pinus brutia Ten.) meşcerelerinden seçilen 486 örnek ağaçtan elde edilen veriler kullanılmıştır (Kahriman ve ark., 2016). Ağaç 
hacim denklemlerinin oluşturulmasında kullanılan örnek ağaçların çap ve boy basamaklarına dağılımları Tablo 1'de verilmiştir.

Çalışma kapsamında kesilen örnek ağaçlar çalışma kapsamında alınan örnek alanların göğüs yüzeyi orta ağacını temsil eden ağaçlardan seçilmiştir. Örnek ağaçların kesildiği bu örnek alanların seçiminde Antalya ve Mersin Orman Bölge
Müdürlükleri kapsamındaki meşcerelerin yaş sınıfı, bonitet sınıfı ve sıklık derecelerine göre dağılımı dikkate alınmıştır. Ağaç hacim denklemlerinin oluşturulmasında kullanılan örnek ağaçların seçiminde; ağaçların değişik çap ve boy kademesinde, canll, tepesi sağlam, tek gövdeli ve sağlıklı olmasına özen gösterilmiştir (Kapucu ve ark., 2002). Dikili kuru, hastalıklı, tepesi kırık, çürük ve kovuk gibi ağaçlar örnek ağaç olarak seçilmemiştir.

Tablo 1. Ağaç hacminin belirlenmesinde kullanılan ağaçların çap ve boy basamaklarına dağılımı

\begin{tabular}{|c|c|c|c|c|c|c|c|c|c|c|c|c|c|c|c|}
\hline \multirow{2}{*}{$\begin{array}{l}\text { Çap } \\
\text { (cm) }\end{array}$} & \multicolumn{14}{|c|}{ Boy (m) } & \multirow{2}{*}{$\sum$} \\
\hline & 2 & 4 & 6 & 8 & 10 & 12 & 14 & 16 & 18 & 20 & 22 & 24 & 26 & 28 & \\
\hline 4 & 35 & 10 & & & & & & & & & & & & & 45 \\
\hline 8 & & 9 & 5 & 1 & & & & & & & & & & & 15 \\
\hline 12 & & & 7 & 14 & 9 & 1 & & & & & & & & & 31 \\
\hline 16 & & & 1 & 19 & 25 & 15 & 4 & 1 & & & & & & & 65 \\
\hline 20 & & & & 4 & 7 & 13 & 11 & 1 & 1 & & 2 & 1 & & & 40 \\
\hline 24 & & & & & 4 & 15 & 15 & 7 & 8 & 8 & 2 & 1 & & 1 & 61 \\
\hline 28 & & & & & 4 & 5 & 13 & 14 & 13 & 6 & 6 & 3 & & & 64 \\
\hline 32 & & & & & & 2 & 8 & 10 & 12 & 10 & 8 & 1 & 2 & 1 & 54 \\
\hline 36 & & & & & & & 6 & 10 & 11 & 4 & 11 & 5 & 2 & & 49 \\
\hline 40 & & & & & & & 1 & 6 & 10 & 4 & 13 & 2 & 1 & 3 & 40 \\
\hline 44 & & & & & & & & & & 3 & 2 & 3 & 3 & & 11 \\
\hline 52 & & & & & & & & & & & & 2 & & & 2 \\
\hline 56 & & & & & & & & & & 2 & 2 & 1 & & 1 & 6 \\
\hline 60 & & & & & & & & & & & 1 & 1 & & & 2 \\
\hline 64 & & & & & & & & & & 1 & & & & & 1 \\
\hline$\sum$ & 35 & 19 & 13 & 38 & 49 & 51 & 58 & 49 & 55 & 38 & 47 & 20 & 8 & 6 & 486 \\
\hline
\end{tabular}

Antalya ve Mersin Orman Bölge Müdürlüklerindeki Kızılçam meşcerelerinden seçilen 486 adet örnek ağaç kesilerek, gövde dipten tepeye doğru önce 1 , sonra 2 'şer $\mathrm{m}$ olacak şekilde $(0.3,1.3,3.3,5.3 \mathrm{~m} \ldots)$ seksiyonlara ayrılmıştır. Genellikle 2'şer m $(0.30-2.30,2.30-4.30 \mathrm{~m}, \ldots)$ ara ile enine kesitler alınırken, üretim standardizasyonuna bağlı olarak bazı ağaçlarda farklı uzunluklarda kesitler alınmıştır. Daha sonra gövde analizi için, her bir kesitin özünden kabuğuna doğru, birbirine dik yönlü cetvel konularak fotoğrafı çekilmiştir. Bu ağaçlarda 5'er yıllık periyotlarda yıllık halka kalınlıkları Yıllık Halka Ölçer ile mm duyarlığında ölçülmüştür. Bu veriler kullanılarak 6033 adet ağaç verisi türetilmiştir. Böylece 5'er y1llık periyotlardaki hacimler ayrı birer ağaçmış gibi elde edilmiştir. Her bir örnek ağacın periyotları; dip kütük, seksiyonlar ve uç parça olmak üzere üç ayrı bölümde hacimlendirilmiş ve bunların toplanması ile de periyotlardaki toplam gövde hacmi hesaplanmıştır. Dip kütüğün silindir, uç parçanın ise koni biçiminde olduğu varsayılmıştır. Seksiyon uzunlukları eşit olmadığından her bir seksiyonun hacimlendirilmesinde "Smalian" formülü kullanılmıştır. Aşağıdaki tabloda bu 486 örnek ağaçtan türetilen 6033 yeni örnek ağaç verisine ilişkin istatistiksel bilgiler verilmiştir (Tablo 2).

$\mathrm{Bu}$ çalışmada, yetişme ortamı verim gücünün belirlenmesinde Genelleştirilmiş Cebirsel Fark Yaklaşımları (GADA) ile elde edilmiş bonitet endeks modellerine dayanan polimorfik yöntem kullanılmıștır. Bu yöntem ile örnek alanların bonitet endeksi ve bonitet 
sinıfi belirlendikten sonra örnek alanlar içerisinde hacim için kesilen ağaçların bonitet sınıfı belirlenmiştir. Çalışma kapsamında standart yaş 60 yıl alınarak standart yaştaki en büyük ve en küçük boy değerlerinin farkları dikkate alınarak, 3 bonitet sinifi oluşturulmuştur. Buna göre düzenlenen bonitet sınıflarının sınır değerleri I. bonitet sınıf için 23.5-30.5, II. bonitet sınıfı için 16.523.5 ve III. bonitet sınıfi için 9.5-16.5 m olarak belirlenmiştir (Kahriman ve ark., 2016).

Tablo 2. Örnek ağaçlara (6033 ağaç verisi) ilişkin çeşitli istatistiksel bilgiler

\begin{tabular}{|c|c|c|c|c|c|c|c|c|c|c|c|}
\hline \multirow[b]{2}{*}{$\begin{array}{l}\text { Bon. } \\
\text { Sinifi }\end{array}$} & \multirow[b]{2}{*}{$\begin{array}{c}\text { Değişke } \\
n\end{array}$} & \multicolumn{5}{|c|}{ Model Verileri (4826 adet) } & \multicolumn{5}{|c|}{ Kontrol Verileri (1207 adet) } \\
\hline & & $\begin{array}{c}\text { Veri } \\
\text { Sayls } \\
1\end{array}$ & Ort. & $\begin{array}{c}\text { Min } \\
.\end{array}$ & Mak. & $\begin{array}{l}\text { Standart } \\
\text { Sapma }\end{array}$ & $\begin{array}{c}\text { Veri } \\
\text { Sayls } \\
1\end{array}$ & Ort. & $\begin{array}{c}\text { Min } \\
\cdot\end{array}$ & Mak. & $\begin{array}{l}\text { Standart } \\
\text { Sapma }\end{array}$ \\
\hline \multirow{4}{*}{ I } & $\mathrm{d}(\mathrm{cm})$ & \multirow{4}{*}{1347} & 21.8 & 2.1 & 63.5 & 11.6 & \multirow{4}{*}{347} & 21.8 & 2.3 & 64.1 & 10.7 \\
\hline & $\mathrm{h}(\mathrm{m})$ & & 13.2 & 2.0 & 33.9 & 6.3 & & 13.4 & 2.0 & 29.9 & 6.4 \\
\hline & $\mathrm{t}(\mathrm{y} 1 \mathrm{l})$ & & 35.3 & 5.0 & 165.0 & 21.8 & & 35.6 & 5.0 & 115.0 & 21.8 \\
\hline & $\mathrm{V}\left(\mathrm{dm}^{3}\right)$ & & 396.0 & 2.0 & 3697.9 & 481.5 & & 373.4 & 2.4 & $\begin{array}{c}3431 . \\
1\end{array}$ & 485.2 \\
\hline \multirow{4}{*}{ II } & $\mathrm{d}(\mathrm{cm})$ & \multirow{4}{*}{2221} & 21.5 & 2.1 & 62.2 & 11.0 & \multirow{4}{*}{553} & 20.9 & 2.1 & 59.4 & 11.9 \\
\hline & $\mathrm{h}(\mathrm{m})$ & & 13.0 & 2.0 & 30.0 & 6.0 & & 12.4 & 2.0 & 29.1 & 6.3 \\
\hline & $\mathrm{t}(\mathrm{y} 1 \mathrm{l})$ & & 50.6 & 5.0 & 160.0 & 30.4 & & 48.6 & 6.0 & 150.0 & 30.0 \\
\hline & $\mathrm{V}\left(\mathrm{dm}^{3}\right)$ & & 352.0 & 2.0 & 3167.2 & 404.4 & & 352.4 & 2.1 & $\begin{array}{c}2805 . \\
4\end{array}$ & 404.6 \\
\hline \multirow{4}{*}{ III } & $\mathrm{d}(\mathrm{cm})$ & \multirow{4}{*}{1251} & 19.8 & 2.1 & 58.2 & 10.1 & \multirow{4}{*}{307} & 19.9 & 2.3 & 56.6 & 10.6 \\
\hline & $\mathrm{h}(\mathrm{m})$ & & 11.8 & 2.0 & 28.1 & 5.0 & & 11.9 & 2.1 & 25.0 & 4.6 \\
\hline & $\mathrm{t}(\mathrm{y} 1 \mathrm{l})$ & & 63.9 & 10.0 & 158.0 & 34.3 & & 65.5 & 10.0 & 158.0 & 34.8 \\
\hline & $\mathrm{V}\left(\mathrm{dm}^{3}\right)$ & & 313.6 & 2.1 & 2314.0 & 405.0 & & 328.4 & 2.2 & $\begin{array}{c}2533 . \\
3\end{array}$ & 412.3 \\
\hline
\end{tabular}

Burada d:gögüs çapını, h:ağaç boyunu, t:ağaç yaşını ve V:ağaç hacmini göstermektedir.

Ağaç hacim tablolarının düzenlenebilmesi için ağaçların kabuklu gövde hacmine ek olarak kabuklu göğüs çaplarının da bilinmesi gerekmektedir. Gövde analizi yapılan ağaçların sadece son periyotlarında (ağaç yaşı) kabuklu çap ölçümü yapıldığından, diğer periyotlardaki ölçülen çap değerleri kabuksuz çaplardır. Bundan dolayı, öncelikle periyotlarda ölçülen kabuksuz çaplar kabuklu çaplara dönüştürülmüş ve ondan sonra analizlere konu edilmiştir. Kabuklu çap ile kabuksuz çap arasındaki ilişkiyi belirlemede ağaçların gövde analizinde son periyottaki kabuksuz çapları (dkbs) ile kabuklu çapları (dkbl) verileri kullanılmıştır.

$\mathrm{Bu}$ çalışma kapsamında ağaç hacim tablosunun düzenlenmesinde, göğüs çapı (d) ve ağaç boyu (h) değişkenleri ve bu değişkenlerden türetilen birçok yeni değişken hacimle ilişkiye getirilmiştir. Analiz sonucunda istatistiksel olarak en az $\mathrm{p}<0.05$ önem düzeyi ile ilişki gösteren değişkenler ile hacim fonksiyonları oluşturulmuştur. $\mathrm{Bu}$ işlemler SPSS (SPSS 19.0 Institute Inc., 2010) adlı istatistik yazılım programı yardımıyla, "İleri Doğru Seçim (Forward Selection)", "Geriye Doğu Seçim (Bacward Selection)" ve "Aşamalı Regresyon (Stepwise Selection)" yöntemleri olarak isimlendirilen Regresyon analizinde değişken belirleme yöntemleriyle yapılmıştır.

Çalışma kapsamında tek girişli, bonitete dayalı tek girişli ve çift girişli ağaç hacim tabloları düzenlenmiştir. Burada, daha önceki ağaç hacim fonksiyonlarından farklı olarak her bir bonitet sınıfı için ayrı tek girişli ağaç hacim fonksiyonları belirlenmiştir. Bonitet sınıfları bazında tek girişli ağaç hacim tabloları, tek girişli ağaç hacim tablolarının bir eksikliği olan yetişme ortamı koşullarını dikkate almaması ve dolayısıyla temsil kabiliyetinin düşüklüğünü gidermek için düzenlenmiştir.

Çalışma kapsamında tek girişli, bonitette dayalı tek girişli ve çift girişli ağaç hacim fonksiyonlarından beklenen büyüme yasaları 
ile uyumlu özellikleri taşıyan, düzeltilmiş belirtme katsayısı $\left(R_{\text {düz. }}^{2}\right)$ değeri yüksek ve standart hata $\left(\mathrm{S}_{\mathrm{y} . \mathrm{x}}\right)$, Toplam Hata Yüzdesi

\section{Belirtme Katsayısı}

Tahminin Standart Hatas1

Ortalama Mutlak Hata Yüzdesi (\%OMH)

Toplam Hata Yüzdesi (\%TH)

Burada, N: veri sayını, p: parametre sayısını, $V_{i}=$ örnek ağaçların hesaplanan hacim değerini, $\widehat{V}_{i}=$ örnek ağaçların model ile tahmin edilen hacim değerini, $\bar{y}_{i}=$ örnek ağaçların ölçülen ortalama hacim değerini göstermektedir.

Hacim denklemlerinin meşcereye uygunluğu, denklemlerin oluşturulmasında kullanılan örnek ağaçlardan bağımsız olarak seçilen örnek ağaç verileri yardımıyla yapılmaktadır (Loetsch ve ark., 1973; Kalıpsız, 1999; Laar ve Akça, 1997). Grup II olarak verilen toplam örnek ağaç sayısının \%20'sini (1207 veri) oluşturan örnek ağaç bu amaçla seçilmiştir. Bu ağaçların Bölümleme Yöntemi ile hesaplanan hacim değerleri $\left(\mathrm{V}_{\mathrm{i}}\right)$ ile oluşturulan tek ya da çift girişli hacim denklemlerinden hesaplanan hacim değerlerinin $\left(\widehat{V}_{i}\right)$, parametrik test varsayımlarının gerçekleşmesi durumunda "Eşlendirilmiş Örnekler için t Testi (Paired Samples t Test)", bu varsayımların gerçekleşmemesi durumunda, parametrik olmayan testlerden "Wilcoxon Testi" ile karşılaştırılarak meşcereye uygun olup olmadıkları denetlenebilmektedir (Kalıpsız, 1988; Batu, 1995). Bu çalışmada, grup varyansları $\alpha=0.05$ önem düzeyi ile homojen, grupların örnek sayıları yeterli büyüklükte ve normal dağılımlı olması nedeniyle "Eşlendirilmiş Örnekler için t Testi (Paired Samples t Test)" ile karşılaştırma yapılmıştır. İlgili test "SPSS" adll bir paket program yardımıyla uygulanmıştır.

\section{Bulgular ve Tartışma}

Tek girişli ağaç hacim tablosunda ağaçlar, bonitet sınıfı ayrımı yapılmaksızın bir bütün
(\%TH) ve Ortalama Mutlak Hata Yüzdesi $(\% \mathrm{OMH})$ değerleri düşük modeller seçilmiştir (Kalıpsız, 1999).

$$
\begin{gathered}
R_{\text {düz. }}^{2}=1-\left(\frac{\sum\left(\mathrm{V}_{\mathrm{i}}-\widehat{\mathrm{V}}_{\mathrm{i}}\right)^{2}}{\sum\left(\mathrm{V}_{\mathrm{i}}-\overline{\mathrm{V}}_{\mathrm{i}}\right)^{2}}\right) \\
\mathrm{S}_{\mathrm{y} . \mathrm{x}}=\sqrt{\frac{\sum\left(\mathrm{V}_{\mathrm{i}}-\widehat{\mathrm{V}}_{\mathrm{i}}\right)^{2}}{\mathrm{~N}-\mathrm{p}}} \\
\% O M H=100 \times \frac{\sum\left|\widehat{V}_{i}-V_{i}\right|}{\sum V_{i}} \\
\% T H=100 \times \frac{\sum \widehat{V}_{i}-\sum V_{i}}{\sum V_{i}}
\end{gathered}
$$

olarak ele alınmıştır. Bu doğrultuda tek girişli ağaç hacim tablosu üretmek için, gövde analiziyle elde edilen 6033 ağaç verisinden, \%80'i (4826'sı) kullanılmıştır. Tek girişli ağaç hacim denkleminin belirlenmesinde göğüs çap1 ve bu çap değişkeninden türetilen yeni değişkenler kullanılmıştır.

Bonitete dayalı tek girişli ağaç hacim denklemi geliştirmek için bonitet sınıfları itibariyle kabuklu gögüs çapları ile ağaç hacimleri ilişkiye getirilmiştir. Bunun için verilerin \%80'i (6033 ağaç verisinin 4826 adedi) her bonitet sınıfı için ayrı olmak üzere regresyon analizine tabi tutulmuşlardır. Buna göre toplam 4826 ağaç verisinin, 1347 adedi I. Bonitet sinıfi, 2238 adedi II. Bonitet sinifi ve 1251 adedi ise III. Bonitet sınıfı için bonitete dayalı ağaç hacim denklemlerinin elde edilmesinde kullanılmıştır.

Antalya ve Mersin Orman Bölge Müdürlüğündeki Kızılçam meşcereleri için çift girişli ağaç hacim denkleminin düzenlenmesinde, gögüs çap1 (d) ile ağaç boyu (h) ve bu iki değişkenden türetilen yeni değişkenler kullanılmıştır. En iyi çift girişli ağaç hacim denklemini belirlemek için 6033 ölçüm verisinden \%80'i (4826) regresyon analizine tabi tutulmuştur.

Çalışma kapsamında ağaç hacmine ilişkin elde edilen tek girişli, bonitete dayalı tek girişli ve çift girişli ağaç hacim modelleri aşağıda ve modellere ilişkin istatistiksel bilgiler de Tablo 3 'te verilmiştir. Ayrıca, ağaç hacim modellerindeki tüm parametreler \% 5 önem düzeyinde istatistiksel olarak anlamlidir. 
Tek Girişli

Tek Girişli (I.Bonitet Sınıfı)

Tek Girişli (II.Bonitet Sınıfi)

Tek Girişli (III.Bonitet Sınıfı)

Çift Girişli

$$
\begin{aligned}
& V=0.1654 x d^{2.3784} \\
& V=0.1655 x d^{2.3999} \\
& V=0.1569 x d^{2.3965} \\
& V=0.1855 x d^{2.3216}
\end{aligned}
$$

Tablo 3. Ağaç hacim denklemlerine ilişkin ölçüt değerleri

\begin{tabular}{lccccc}
\hline \multicolumn{1}{c}{ Denklem } & $\mathrm{R}^{2}$ & $\mathrm{~S}_{\mathrm{yx}}$ & $\% \mathrm{TH}$ & $\% \mathrm{OMH}$ & $\mathrm{df}$ \\
\hline Tek Girişli & 0.975 & 52.84 & -0.457 & 9.756 & - \\
Tek Girişli (I.BS) & 0.978 & 44.84 & -0.438 & 9.849 & - \\
Tek Girişli (II.BS) & 0.976 & 54.45 & -0.464 & 9.501 & - \\
Tek Girişli (III.BS) & 0.969 & 52.96 & -0.452 & 9.256 & - \\
Çift Girişli & 0.992 & 41.26 & 0.210 & 5.038 & 1.009
\end{tabular}

Burada: df düzeltme faktörü

Yukarıdaki denklemlerden çift girişli ağaç hacim denkleminin katsayıları, logaritmik değerler üzerinden hesaplandıkları için sistematik bir hata söz konusudur (Akalp, 1978). Bu sistematik hatanın giderilmesi için, regresyon denklemleri ile elde edilen değerler bir düzeltme faktörü ile çarpılmalıdır. Bu çalışmada, doğal logaritma (Ln) düzeltme faktörü (Baskerville, 1972);

$$
d f=e^{\frac{S_{y \cdot x}^{2}}{2}}
$$

eşitliği ile hesaplanmıştır. Bu eşitlikte, e, doğal logaritmayı (2.718281828) ve $\mathrm{S}_{\mathrm{y} . \mathrm{x}}$, denklemin standart hatasını ifade etmektedir.

Ağaç hacim denklemlerinde elde edilen toplam hata yüzdesinin \% 1'den daha düşük ve ortalama mutlak hata yüzdesinin ise \%10'dan daha düşük olması önerilmektedir (Bruce, 1920; Chapman ve Meyer, 1949; Loetsch ve ark., 1973; Husch, 1963; Özer ve Uğurlu 1977; Çevik 1993). Bruce'a göre toplam farkın $\pm \% 0,5$ 'ten daha küçük olması gerekir. Bu fark $\pm \%$ 1'e kadar kabul edilebilir. Bunu aşması durumunda hata yapılmış olunur (Husch, 1963). Böyle hallerde yeni tabloların düzenlenmesi gerekir.
$\mathrm{Bu}$ çalışma kapsamında üretilen tek girişli, bonitete dayalı tek girişli ve çift girişli ağaç hacim modellerinin hem toplam hata hem de ortalama mutlak hata yüzdeleri kabul edilen hata sınırlarını aşmamaktadır. Şöyle ki: Toplam Hata Yüzdeleri (\%TH) Kızılçam tek girişli, I. bonitet, II. bonitet, III. bonitet ve çift girişli modeller için sırasıyla, $-0.457,-0.438$, $0.464,0.210$ olarak elde edilmiştir. Diğer taraftan aynı modellerin Ortalama Mutlak Hata Yüzdeleri (\%OMH) tek girişli, I. bonitet, II. bonitet, III. bonitet ve çift girişli modeller için sirasiyla, 9.756, 9.849, 9.501, 9.256 ve 5.038 'dir. $\mathrm{Bu}$ da bu modellerin kabul edilebilir olduklarını ve çalışma alanlarındaki meşcerelerde ağaçların hacimlerinin doğruya yakın tahmin edilebileceklerini göstermektedir.

Ağaç hacim denkleminin meşcereye uygun olup olmadığının testi için önce " $F$ " testi ile grup varyansları karşıllaştırılmıştır. Toplam örnek ağaç sayısının \%20"sini oluşturan örnek ağaç verileri bu amaçla seçilmiştir. Verilere iliş̧in $F$ istatistik değerleri $\mathrm{p}>0.05$ olduğundan grup varyanslarının homojen olduğu sonucuna varılmıştır (Tablo 4). Varyanslar homojen olduğundan, iki bağımlı grup için 
Eşlendirilmiş Örneklem $\mathrm{t}$ Testi (Paired Sample t Test) ile karşılaştırılmış ve t istatistik sonuçlarına göre önem düzeyi $\mathrm{p}<0.05$ olduğundan gözlenen (ölçülen) ve tahmin edilen veriler arasında bir farklılığın olmadığ belirlenmiştir. Böylece düzenlenen Kızılçam ağaç hacim denklemlerinin örnek ağaçların alındığı Kızılçam meşcereleri için uygun olduğunu söyleyebiliriz (Tablo 4).
Çalışma kapsamında elde edilen Kızılçam ağaç türüne ilişkin tek girişli ağaç hacim modeli ve bonitete dayalı tek girişli ağaç hacim modelleri, Carus ve Su (2014) tarafindan, Antalya-Korkuteli Yöresi Kızılçam ağaçlandırmaları için ve Sun ve ark., (1978) tarafından da çeşitli yetişme ortamları için oluşturulan tek girişli ağaç hacim modelleriyle kıyaslanmıştır (Şekil 2).

Tablo 4. Ağaç hacim denklemlerinin kontrolüne ilişkin t-testi sonuçları

\begin{tabular}{lcccc}
\hline \multirow{2}{*}{ Denklem } & \multicolumn{2}{c}{$\begin{array}{c}\text { Varyansların Eşitliği } \\
\text { (Levene istatistiği) }\end{array}$} & \multicolumn{2}{c}{ t-testi sonuçları } \\
\cline { 2 - 5 } & $\mathrm{F}$ & $\mathrm{p}$ & $\mathrm{t}$ & $\mathrm{p}$ \\
\hline Tek Girişli & 0.072 & 0.788 & -1.275 & 0.203 \\
Tek Girişli (I.BS) & 0.010 & 0.922 & 1.585 & 0.114 \\
Tek Girişli (II.BS) & 0.026 & 0.872 & 0.781 & 0.435 \\
Tek Girişli (III.BS) & 0.024 & 0.878 & 0.893 & 0.373 \\
Çift Girişli & 0.005 & 0.944 & 0.650 & 0.526 \\
\hline
\end{tabular}

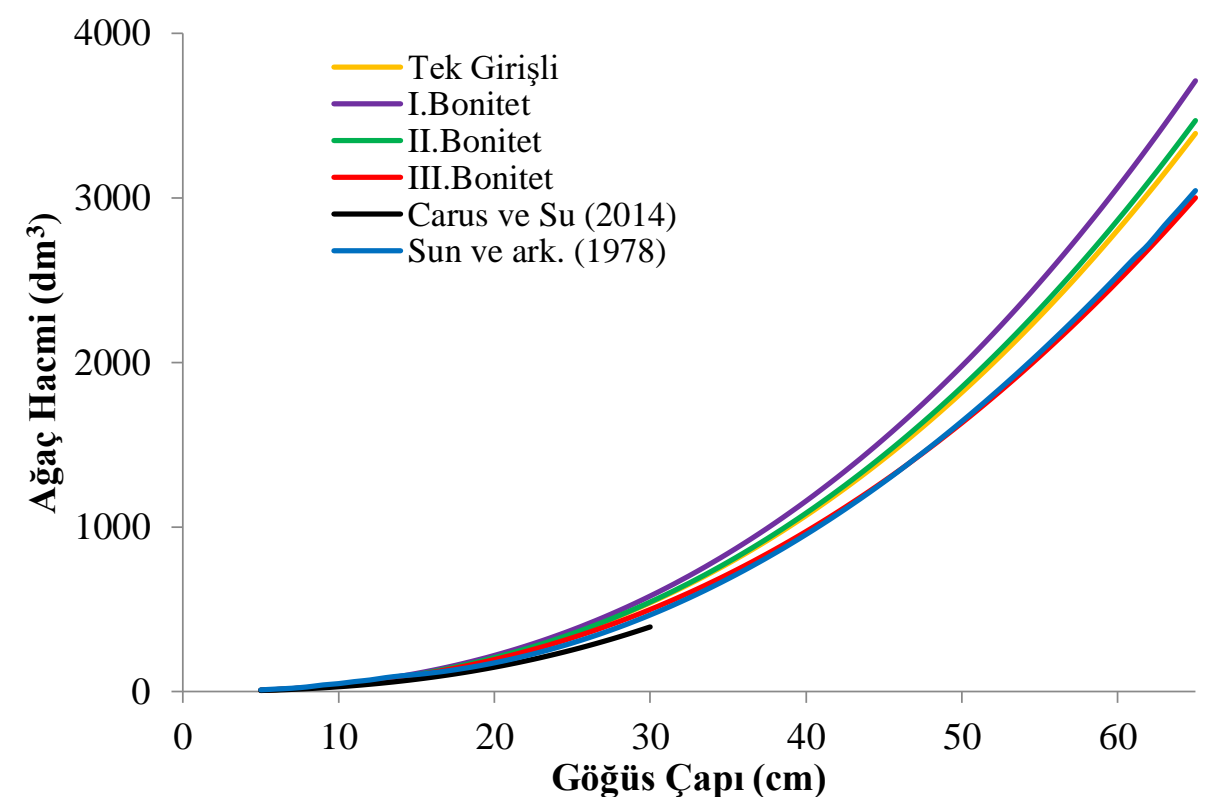

Şekil 2. Ağaçların hacimlerinin gögüs çapı ve ağaç boyuna göre değişimi

Şekil 2 incelendiğinde; çalışma kapsamında üretilen tek girişli ağaç hacim modelinin; Carus ve Su (2014) tarafindan oluşturulan ağaç hacim modeline göre hep daha yüksek; Sun ve ark., (1978) tarafindan yapılan çalışmadan da $12 \mathrm{~cm}$ çapa kadar düşük, sonraki çaplarda daha yüksek sonuç verdiği görülmektedir. Bu farkın, Carus ve $\mathrm{Su}$ (2014)'nun çalışmasının ağaçlandırma alanlarındaki bu çalışmanın ise doğal Kızılçam meşcerelerinde yapılması; Sun ve ark. (1978)'nın çalışması Türkiye genelini 
kapsıyorken, bu çalışmanın daha belirgin bir yörede (yöresel) olmasından kaynaklandığ1 düşünülmektedir. Diğer taraftan, Antalya ve Mersin yöresi, kızılçam ağacının daha iyi yetişebileceği yörelerden olmasından dolayı da bu farklılık meydana gelmiş olabilir.

Ayrıca bu çalışmada üretilen tek girişli ağaç hacim modeli ile bonitete dayalı tek girişli ağaç hacim modelleri de kıyaslanmıştır.
Bunun için modellerin uygunluğunda kullanılan bağımsız veriler, her iki yönteme göre de hacimlendirilerek ortalamalar, aralarındaki farklar ve oranlar hesaplanmışıtır (Tablo 5). Tablodaki ortalama fark, tek girişli ağaç hacim tablo değerinden ilgili bonitet sınıfı tablo değerinin farkı alınarak; ortalama fark yüzdesi de bu farkın tek girişli değerlere göre yüzdesi alınarak hesaplanmıştır.

Tablo 5. Tek girişli ağaç hacim modeli ile bonitete dayalı tek girişli ağaç hacim modellerinin kıyaslanması

\begin{tabular}{cccccccc}
\hline $\begin{array}{c}\text { Bonitet } \\
\text { Sinıfı }\end{array}$ & $\mathrm{N}$ & $\begin{array}{c}\text { Ortalama } \\
\text { Fark }\end{array}$ & $\begin{array}{c}\text { Ortalama Fark } \\
\text { Yüzdesi } \\
(\%)\end{array}$ & $\begin{array}{c}\text { Ortalama Hacim } \\
\text { Tek Girişli } \\
(\mathrm{dm})\end{array}$ & $\begin{array}{c}\text { Ortalama } \\
\text { Hacim } \\
(\mathrm{dm} 3)\end{array}$ & $\mathrm{t}$ & $\mathrm{p}$ \\
\hline I & 347 & -25.72 & $-6,32$ & 337.71 & 363.44 & - & $<0.05$ \\
II & 553 & -1.79 & -0.45 & 332.46 & 334.25 & -1.88 & 0.06 \\
III & 307 & 21.68 & 4.28 & 312.07 & 290.39 & 11.64 & $<0.05$ \\
\hline
\end{tabular}

Tablo 5'e göre I. ve III. Bonitet Sinıflarında önem düzeyleri $\% 5$ 'den küçük olduğundan tek girişli model ile I. ve III. bonitete dayalı tek girişli modeller arasında istatistiki olarak anlamlı farklılığın olduğu, II. Bonitet Sınıfinda ise $\mathrm{p}$ değeri, 0,05 'ten $(\mathrm{p}=0,06)$ büyük olduğundan tek girişli model ile II. Bonitet Sınıfı için bonitete dayalı tek girişli model arasında istatistiki olarak bir fark olmadığ1 anlaşılmıştır. Böyle bir sonuç beklentileri karşılamaktadır. Yani Kızılçam meşçereleri için geliştirilen tek girişli ağaç hacim modelleri istatistiksel olarak, I. bonitet sınıfındaki ağaçlar için düşük, III. Bonitet sınıfındaki ağaçlar için yüksek tahminler verirken, II. bonitet sınıfındaki ağaçlar için benzer tahminler vermektedir. Tabloda da görüldüğü üzere, tek girişli ağaç hacim tablosu değeri, I. ve II. Bonitet Sinıflarında bonitete dayalı tek girişli ağaç hacim modelleri değerinden düşük olup bu fark I. Bonitet Sınıfı için \%-6.32 ve II. Bonitet Sınıfı için ise \%-0.45'dir. Oysa III. Bonitet Sınıfında tek girişli ağaç hacim modeli, bonitete dayalı tek girişli ağaç hacim modelinden $\% 4.28$ daha büyük değerler vermektedir. Bunun anlamı hacimlendirme yapılırken tek girişli ağaç hacim modeli kullanıldığı zaman I. ve II. bonitet sınıflarında düşük değerler elde edilirken, III. bonitet sınıfında ise yüksek değerler elde edilmektedir.
Çalışma kapsamında elde edilen çift girişli ağaç hacim modeli; Carus ve Su (2014)'nun, Antalya-Korkuteli Yöresi Kızılçam ağaçlandırmaları için; Çatal (2009)'ın, Batı Akdeniz Kızılçam meşcereleri için; Usta (1991)'nın Kızılçam ağaçlandırma alanları için; Sun ve ark., (1978)'nın çeşitli yetişme ortamları için ve Alemdağ (1962)'in ülkemizdeki tüm Kızılçam meşcereleri için yapmış oldukları çift girişli ağaç hacim modelleriyle kıyaslanmıştır (Şekil 3).

Çalışma kapsamında üretilen çift girişli ağaç hacim modeli ile genellikle Usta (1991), Çatal (2009) ve Carus ve Su (2014) tarafindan hazırlanan çift girişli ağaç hacim modellerinden daha yüksek, Alemdağ (1962) ve Sun vd. (1978) tarafından hazırlanan çift girişli ağaç hacim modellerinden daha düşük hacimler elde edilmektedir. Üretilen çift girişli modelin, diğer çalışmalara göre daha yüksek veya daha düşük sonuç vermesi; üretilen çift girişli ağaç hacim modellerinin genel, bölgesel veya yöresel olması, farkl1 yetişme ortamı koşullarında olması, örnek ağaç seçimi yönteminin farklı olması ve model yapılarının farklı olmasından dolayı olabileceği düşünülmektedir. Ayrıca, Carus ve Su (2014) ve Usta (1991) çalışmalarının ağaçlandırma alanlarında yapılmış olması da bu farklılığa neden olduğu düşünülmektedir. 


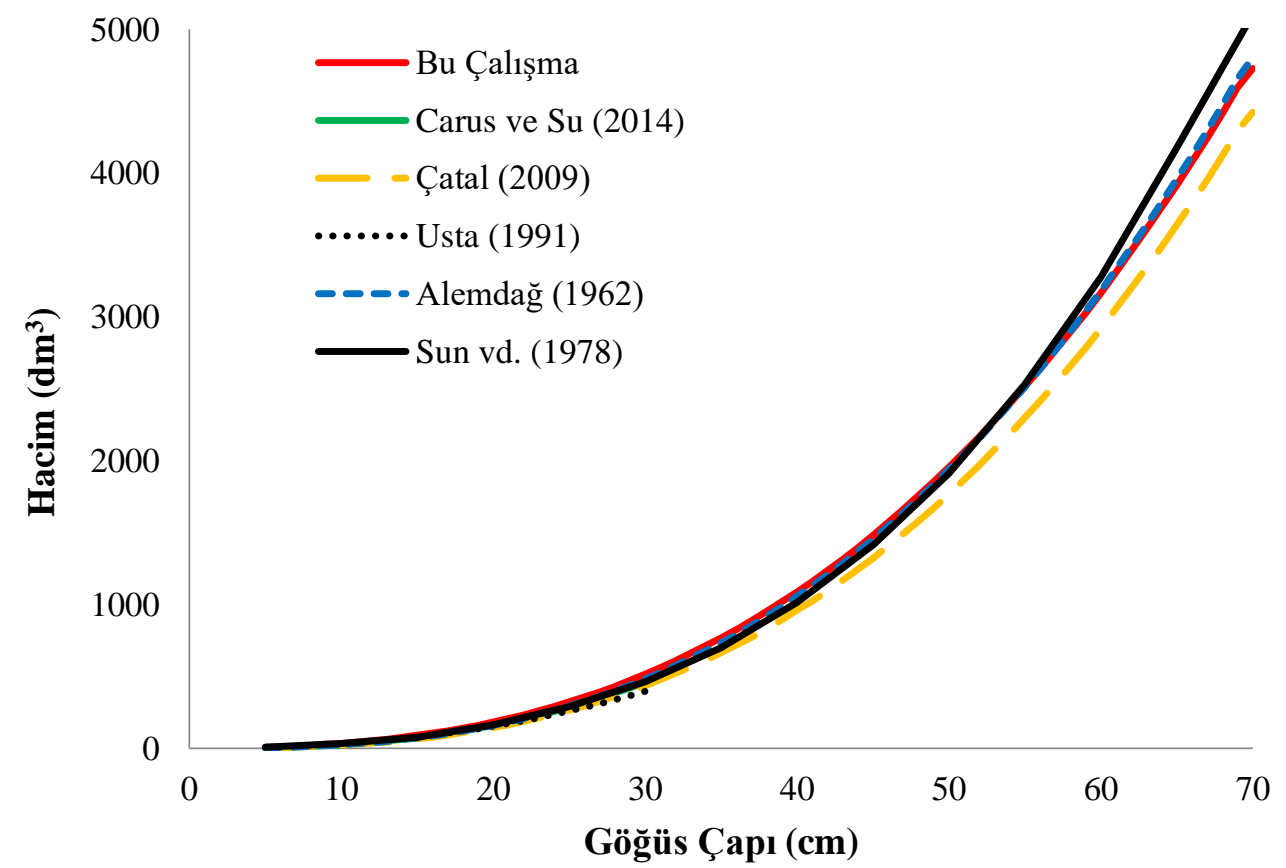

Şekil 3. Çift girişli ağaç hacim modellerinin kıyaslanması

Tablo 6. Ağaç hacim modellerinin diğer yapılan çalışmalar ile kıyaslanması

\begin{tabular}{|c|c|c|c|c|c|c|c|c|c|c|}
\hline \multicolumn{6}{|c|}{ Tek Girişli Ağaç Hacim Denklemleri } & \multicolumn{5}{|c|}{ Çift Girişli Ağaç Hacim Denklemleri } \\
\hline \multirow[t]{2}{*}{ Denklem } & \multirow{2}{*}{$\begin{array}{c}\text { Yapılan } \\
\text { Karşılaştırma }\end{array}$} & \multicolumn{2}{|c|}{$\begin{array}{c}\text { Levene } \\
\text { istatistiği }\end{array}$} & \multicolumn{2}{|c|}{ t testi } & \multirow{2}{*}{$\begin{array}{c}\text { Yapılan } \\
\text { Karşılaştırma }\end{array}$} & \multicolumn{2}{|c|}{$\begin{array}{l}\text { Levene } \\
\text { istatistiği }\end{array}$} & \multicolumn{2}{|c|}{ t testi } \\
\hline & & $\mathrm{F}$ & $\mathrm{p}$ & $\mathrm{t}$ & $\mathrm{p}$ & & $\mathrm{F}$ & $\mathrm{p}$ & $\mathrm{t}$ & $\mathrm{p}$ \\
\hline \multirow[b]{2}{*}{ TekGirişli } & Carus ve $\mathrm{Su}$ & 3,47 & 0,069 & 6,03 & $<0.05$ & \multirow{2}{*}{ Carus ve $\mathrm{Su}$} & \multirow{2}{*}{0,36} & \multirow{2}{*}{0,550} & \multirow{2}{*}{7,42} & \multirow{2}{*}{$<0.05$} \\
\hline & Sun vd. & 0,82 & 0,367 & 8,75 & $<0.05$ & & & & & \\
\hline \multirow{2}{*}{ I Bonitet } & Carus ve $\mathrm{Su}$ & 3,49 & 0,064 & 5,91 & $<0.05$ & \multirow[t]{2}{*}{ Çatal } & \multirow[t]{2}{*}{0,41} & \multirow[t]{2}{*}{0,523} & \multirow[t]{2}{*}{11,08} & \multirow[t]{2}{*}{$<0.05$} \\
\hline & Sun vd. & 2,89 & 0,092 & 8,33 & $<0.05$ & & & & & \\
\hline \multirow{2}{*}{ II Bonitet } & Carus ve $\mathrm{Su}$ & 3,64 & 0,062 & 5,92 & $<0.05$ & Usta & 2,08 & 0,155 & 4,83 & $<0.05$ \\
\hline & Sun vd. & 1,21 & 0,273 & 8,36 & $<0.05$ & Alemdağ & 0,02 & 0,899 & 2,93 & $<0.05$ \\
\hline \multirow{2}{*}{ III Bonitet } & Carus ve $\mathrm{Su}$ & 2,03 & 0,160 & 6,51 & $<0.05$ & \multirow[b]{2}{*}{ Sun vd. } & \multirow[b]{2}{*}{0,13} & \multirow[b]{2}{*}{0,716} & \multirow[b]{2}{*}{$-0,47$} & \multirow[b]{2}{*}{0,638} \\
\hline & Sun vd. & 0,03 & 0,859 & 0,82 & 0,416 & & & & & \\
\hline
\end{tabular}

Çalışma kapsamında elde edilen ağaç hacim denklemleri istatistiksel olarak diğer çalışmalarla karşılaştırılmıştır (Tablo 6). Verilere ilişkin $\mathrm{F}$ istatistik değerleri $\mathrm{p}>0.05$ olduğundan, iki bağımlı grup için ortalamalar Eşlendirilmiş Örneklem $\mathrm{t}$ Testi ile karşılaştırılmıştır. Yapılan değerlendirme sonucunda, bu çalışmada III. bonitete dayalı olarak oluşturulan tek girişli denklem ile Sun ve ark., (1978) tarafından belirlenen tek girişli denklem (t: -0.47 ve $\mathrm{p}: 0.638)$ ve çalışma kapsamında oluşturulan çift girişli denklem ile Sun ve ark., (1978) tarafindan oluşturulan çift girişli denklem (t: 0.82 ve p: 0.416) arasında istatistiksel olarak \% 5 önem düzeyinde bir farklılık olmadığ görülmektedir (Tablo 6). Yapılan diğer kıyaslamalara bakıldığında, istatistiksel olarak model sonuçlarının farklılık oluşturduğu görülecektir.

\section{Sonuç ve Öneriler}

$\mathrm{Bu}$ çalışmada, Antalya ve Mersin yörelerinde yer alan saf ve doğal Kızılçam 
meşcereleri için tek, bonitet dayalı tek ve çift girişli ağaç hacim denklemleri geliştirilmiş ve tabloları düzenlenmiştir (Ek Tablo 1 ve 2)

Çalışma kapsamında elde edilen sonuçlara göre hem hacimdeki değişkenliği belirlemedeki başarısı hem de standart hata, toplam hata ve ortalama mutlak hata değerleri bakımından düşük hatalı olması nedeniyle en başarılı yöntem, çift girişli ağaç hacim denklemleridir. Bu nedenle hacim belirlerken göğüs çapına ilaveten boy değişkenini de ölçmüşsek kesinlikle çift girişli ağaç hacim denklemini kullanarak ağaçların hacimlerini belirlememiz daha doğru olacaktır. Diğer taraftan ağaçların boyunu ölçmemiş isek ve o tür için çap-boy denklemi üretilmişse ve ağaç kesimi yapılan yöreye uygunsa veya kullanılabilecekse, bu durumda yine çift girişli ağaç hacim denklemini kullanarak hacim belirlememiz uygun olacaktır. Ayrica Orman Genel Müdürlüğü-299 sayı1ı (Anonim, 2014) tebliğe (Ekosistem Tabanl1 Fonksiyonel Orman Amenajman Planlarının Düzenlenmesine Ait Usul Ve Esaslar) göre meşçere tiplerine göre çap-boy grafiği elde edilmiş ise gögüs çapları ölçülen ağaçların boyları bu grafikler yardımıyla elde edilerek çift girişli ağaç hacim denklemleri yardımıyla hacimler belirlenebilir. Ancak amenajman planları yapılırken boy ölçümü yapılmamaktadır ve bu çap-boy grafikleri de elde edilmemişse çift girişli ağaç hacim denklemi kullanılamaz. Bununla birlikte meşçere tiplerine göre çap-boy grafikleri elde edilmiş olsa bile aynı meşçere tipinin farklı verim sınıfındaki yerlerdeki çap-boy grafiği diğer bir deyişle göğüs çaplarına karşıllk gelen boy değerleri aynı almayacaktır. Böyle bir durumda meşçere verim gücü önemlilik arz etmekte ve bu durumda dikkate alınarak aynı meşçere tipi olsa bile yetişme ortamı koşulları farklı olan meşcereler için çap-boy grafikleri ayrı olacak şekilde elde edilmesi daha doğru olacaktır.

Herhangi bir şekilde ağaçların boyu ölçülememiş veya denklem veya grafiklerle elde edilemiyorsa, tek veya bonitete dayalı tek girişli ağaç hacim denklemlerinin kullanılması kaçınılmaz olacaktır. İstatistiki olarak tek girişli denklem ile bonitete dayalı tek girişli denklemler arasında istatistiki açıdan anlamlı farlılıklar olduğu görülmektedir. Ancak bonitete dayalı ağaç denklemlerinin hem hacimdeki değişkenliği ortaya koymasındaki başarıları hem de denklemlerdeki hata oranlarının birbirine yakın olmasından dolayı tek girişli ağaç hacim denklemlerine göre önemli oranda başarılı oldukları söylenemez. Daha önceden de buna benzer çalışmalar veya değerlendirmeler yapılmak istenmiştir. Sun ve ark. (1978) tarafından yapılan çalışmada, Kızılçam ve diğer türlerde bonitetlere göre tek ve çift girişli hacim tablolarının düzenlenmesi düşünülmüş ancak, örnek ağaç ve alanların boy/yaş, hacim/yaş ilişkilerinin hesaplanması için gerekli dağılım sağlanamamıştır.

Çift girişli ağaç hacim tablolarının tek girişli olanlara göre doğruya daha yakın sonuç verdiği bilinmektedir. Ancak gerek planlama gerekse uygulama aşamasında orman işletmeleri daha pratik olması açısından tek girişli ağaç hacim tablolarını kullanmaktadırlar. Bunun için ya ağaçların gögüs çaplarına ilaveten boylarını da ölçerek hacimlerini daha doğru bir şekilde belirlememiz ya da farklı yetişme ortamı koşullarındaki meşçereler için yöresel tek girişli ağaç hacim denklemleri geliştirmemiz daha doğru olacaktır.

\section{Teşekkür}

Çalışma kapsamında verilerin elde edilmesinde verdiği maddi destekten dolayı, Türkiye Bilimsel ve Teknolojik Araştırma Kurumuna (TÜBİTAK-TOVAG Proje No:112O808; Proje adı: Antalya ve Mersin Yöresi Saf Kızılçam Meşcerelerinde Hasılat Araştırmaları) teşekkür ederiz. Ayrıca proje ekibinin tümüne ve Antalya ve Mersin Orman Bölge Müdürlüklerindeki meslektaşlarımıza ve çalışanlarına teşekkür ederiz.

\section{Kaynaklar}

Akalp, T. 1978. Türkiye'deki Doğu Ladini (Picea orieantalis Lk. Carr) Ormanlarında Hasılat Araştırmaları. Doktora Tezi, İstanbul Üniversitesi, Fen Bilimleri Enstitüsü, İstanbul.

Alemdağ, İ.Ş. 1962. Türkiye'deki Kızılçam Ormanlarının Gelişimi, Hasılat ve Amenajman Esasları. Ormancılık Araştırma Enstitüsü, Teknik Bülten No: 11, Ankara, $160 \mathrm{~s}$.

Anonim. 2014. Ekosistem Tabanlı Fonksiyonel Orman Amenajman Planlarının Düzenlenmesine Ait Usul ve Esaslar, Orman ve Su İşleri Bakanlığı Orman Genel Müdürlüğü Orman İdaresi ve Planlama Daire Başkanlığı, Tebliğ No: 299, 
$10.12 .2014,210 \mathrm{~s}$.

Anonim. 2015. Türkiye Orman Varlığ Orman ve Su İşleri Bakanllğı Orman Genel Müdürlüğü Orman İdaresi ve Planlama Daire Başkanlığı, Ankara.

Anşin, R. 1994. Tohumlu BitkilerGymnospermae (Açık Tohumlular)-I. Cilt-II. Bask1, KTÜ Orman Fakültesi Yayın No: 122/15, Trabzon, $262 \mathrm{~s}$.

Asmaz, H. 1993. Akdeniz Peyzajında Kızılçamın Önemi. Uluslararası Kızılçam Sempozyumu 18-23 Ekim, Bildiriler Kitab1, Marmaris, s. 48-55.

Baskerville, G. 1972. Use of Logarithmic Regression in The Estimation of Plant Biomass, Canadian Journal of Forest Research, 2, 49-53.

Batu, F. 1995. Uygulamalı İstatistiksel Yöntemler. K.T.Ü. Orman Fakültesi Yayın No: 179/22, Trabzon, $312 \mathrm{~s}$.

Brooks, J.R., Jiang, L., Özçelik, R. 2008. Competible Stem Volume and Taper Equations for Brutian Pine, Cedar of Lebanon and Cilicica Fir in Turkey, Forest Ecology and Management, 256, 147-151.

Bruce, D. 1920. A proposed standardisation of the checking of volume tables. Jour. For., $18=5 \mathrm{Jf} 9$ - 557 (original not seen; quoted from forest mensuration and statis- tics by B. Husch, 1963).

Carus, S., Su, Y. 2014. Antalya-Korkuteli Yöresi Kızılçam Ağaçlandırmaları İçin Tek ve Çift Girişli Ağaç Hacim Tablosunun Düzenlenmesi ve Mevcut Tablolar ile Kiyaslanmasi. II. Ulusal Akdeniz Orman ve Çevre Sempozyumu, 22-24 Ekim, Bildiriler Kitab1, Isparta, s. 574-584.

Chapman, H.H., Meyer, W.H. 1949. Forest Mensuration, McGraw-Hill Book Compamy, Inc.

Clark, A., Souther, R. A., Schlaegel, B.E., 1991. Stem Profile Equations For Southern Tree Species. USDA Forest Service Research Paper, SE-282.

Çatal, Y. 2009. Batı Akdeniz Bölgesi Kızılçam (Pinus brutia Ten.) meşcerelerinde Artım ve Büyüme. Doktora Tezi, Süleyman Demirel Üniversitesi Fen Bilimleri Enstitüsü, Isparta, 281 s.

Çevik, İ. 1993. Boşaltma Aşamasına Gelmiş Kızılçam Meşcerelerinde Dikili Ağaç Hacminin Belirlenmesi, Orman Bakanlığı, Ege Ormancılık Araştırma Enstitüsü Müdürlüğü, Teknik Bülten No:6.

Davis, P.H. 1982. Flora of Turkey and the East Aegean Islands. Edinburgh, UK: Edinburgh University Press.

Demaerschalk, J. P. 1972. Converting volume equations to compatible taper equations. Forest Science, 18, 241-245.

Husch, B. 1963. Forest Mensuration. The Ronald Press Company, 402p., New York.
Kahriman, A., Sönmez, T., Yavuz, M., Şahin, A., Yılmaz, S., Uzun, M., Kumaş, G., Genç, Y. 2016, Antalya ve Mersin Yöresi Saf Kızılçam Meşcerelerinde Hasılat Araştırmaları, (TÜBITAK-TOVAG Projesi, Proje No: 1120808), Artvin Çoruh Üniversitesi Orman Fakültesi, Artvin (Basılmamıştır).

Kalıpsı, A. 1988. İstatistik Yöntemler. İ.Ü. yayın No: 3522, İstanbul, $453 \mathrm{~s}$.

Kalıpsiz, A. 1999. Dendrometri, İstanbul Üniversitesi Orman Fakültesi Yayınları, İstanbul.

Kapucu, F. 2004, Orman Amenajmanı, 515 s, K. T. Ü. Yayın No: 215, Trabzon.

Kapucu, F., Yavuz, H., Gül, A.U., Misır, N. 2002. Kestane Meşcerelerinin Hasılat ve Amenajman Esasları. TOGTAG 2229 nolu TÜBİTAK Projesi, 118 s., Ankara.

Kayacık, H. 1965. Orman ve Park Ağaçlarının Özel Sistematiği Gymnospermae (Açık Tohumlular) I. Cilt. İstanbul Üniversitesi Orman Fakültesi Yayın No: 1105/98, İstanbul, $390 \mathrm{~s}$.

Kumaş, G., Kahriman, A. 2016. Antalya Orman Bölge Müdürlüğü'nde yayılış gösteren kızılçam meşcereleri için uyumlu gövde profili denklem sistemlerinin geliştirilmesi, Artvin Çoruh Üniversitesi Orman Fakültesi Dergisi, Cilt: 17, Sayı:1, Sayfa:21-31.

Laar, A.V., Akça, A. 1997. Forest Mensuration. Cuvillier Verlag, Göttingen, 385 s.

Loetsch, F., Zöhrer, F. ve Haller, K.E., 1973. Forest Inventory. Volume II, ISBN 3-405- 108128, BLV Verlagsgesellschaft München Benn Wien, München.

Max, T. A, Burkhart, H. E. 1976. Segmented Polynomial Regression Applied to Taper Equations, Forest Science, 22, 3, 283-289.

Özçelik, R., Brooks, J. R. 2012. Compatible volume and taper models for economicaly 1mportant tree species of Turkey, Annals of Forest Science, 69, 105-118.

Özer, E., Uğurlu, S. 1977. Aynalı Relaskop Fh/d Değerlerinden Elde Edilen ya da Çift Girişli Hacim tablolarına Göre Elde Edilen Hacimlerin Seksiyondan Hesaplanan Hacimlerle Karşılaştırması. Ormancılık Araştırma Enstitüsü Teknik Bülten No 99. Ankara.

Pantelas, V. 1986. The Forests of Brutia Pine in Cyprus. Ciheam. 86(1), 46-46.

SPSS Institute Inc. 2010. IBM SPSS Statistics 19 Core System User's Guide, SPSS Programming and Data Management, $426 \mathrm{~s}$.

Sun, O., Eren, M. E., Orpak, M. 1978. Temel Ağaç Türlerimizde Tek Ağaç ve Birim Alandaki Odun Çeşidi Oranlarının Saptanması. (TÜBİTAK, proje no: TOAG-288), Tarım ve Ormancilık Araştırma Grubu Yayını.

Şentürk, N. 1997. Dişbudak (Fraxinus angustifolia Wahl. subps. oxycarpa (Bieb. Ex 
Willd.) Franco \& Rocha Afonso) Gövde Hacim ve Ağaç Hacim Tablolarının Düzenlenmesi. Yüksek Lisans Tezi, Karadeniz Teknik Üniversitesi Fen Bilimleri Enstitüsü, Trabzon, 97s.

Usta, H. Z. 1991. Kızılçam (Pinus brutia Ten.) Ağaçlandırmalarında Hasılat Araştırmaları. Ormancılık Araştırma Enstitüsü Teknik Yayın Serisi No: 219.

Yavuz, H. 1999. Taşköprü Yöresinde Karaçam İçin Hacim Fonksiyonları ve Hacim Tabloları, Turkish Journal of Agriculture and Forestry, 23, 1181-118.
Yavuz, H., Sakıcı, O.E. 2002. Gövde Profili Modellerinin Bilimsel ve Pratik Açıdan İrdelenmesi. Orman Amenajmanında Kavramsal Açılımlar ve Yeni Hedefler Sempozyumu. 18-19 Nisan 2002, İstanbul, Bildiriler Kitab1.

Yeşil, A. 1992. Değişik Sıklık ve Bonitetlerdeki Kızılçam Meşcerelerinin Yaşa Göre Gelişimi. Doktora Tezi, İstanbul Üniversitesi Fen Bilimleri Enstitüsü, İstanbul, 179 s.

Ek Tablo 1. Kızılçam Tek Girişli ve Bonitete Dayalı Tek Girişli Kabuklu Gövde Hacmi Tablosu

\begin{tabular}{|c|c|c|c|c|c|c|c|c|c|}
\hline \multirow{3}{*}{$\begin{array}{c}\text { Göğüus } \\
\text { Çapı } \\
\text { (cm) }\end{array}$} & \multirow{3}{*}{$\begin{array}{c}\text { Tek } \\
\text { Girişl } \\
\quad \text { i }\end{array}$} & \multicolumn{3}{|c|}{$\begin{array}{c}\text { Bonitete Dayalı Tek } \\
\text { Girişli }\end{array}$} & \multirow{3}{*}{$\begin{array}{l}\text { Göğüs } \\
\text { Çapı } \\
\text { (cm) }\end{array}$} & Tek & \multicolumn{3}{|c|}{$\begin{array}{c}\text { Bonitete Dayalı Tek } \\
\text { Girişli }\end{array}$} \\
\hline & & I.BS & II.BS & III.BS & & & I.BS & II.BS & III.BS \\
\hline & & \multicolumn{3}{|c|}{ Hacim $\left(\mathbf{d m}^{3}\right)$} & & \multicolumn{4}{|c|}{ Hacim $\left(\mathrm{dm}^{3}\right)$} \\
\hline 6 & 11.7 & 12.2 & 11.5 & 11.9 & 36 & 831.9 & 898.9 & 842.0 & 761.2 \\
\hline 8 & 23.3 & 24.3 & 22.9 & 23.2 & 38 & 946.0 & 1023.5 & 958.5 & 863.0 \\
\hline 10 & 39.5 & 41.6 & 39.1 & 38.9 & 40 & 1068. & 1157.5 & 1083.8 & 972.1 \\
\hline 12 & 61.0 & 64.4 & 60.5 & 59.4 & 42 & 1200 & 1301.3 & 1218.3 & 1088.7 \\
\hline 14 & 88.0 & 93.2 & 87.6 & 85.0 & 44 & $\begin{array}{c}1340 . \\
7\end{array}$ & 1455.0 & 1362.0 & 1212.9 \\
\hline 16 & 120.9 & 128.4 & 120.6 & 115.8 & 46 & 1490. & 1618.8 & 1515.1 & 1344.7 \\
\hline 18 & 160.0 & 170.3 & 159.9 & 152.3 & 48 & 1649. & 1792.9 & 1677.7 & 1484.4 \\
\hline 20 & 205.6 & 219.3 & 205.8 & 194.5 & 50 & 1817. & 1977.4 & 1850.2 & 1632.0 \\
\hline 22 & 257.9 & 275.7 & 258.7 & 242.6 & 52 & 1994. & 2172.6 & 2032.5 & 1787.5 \\
\hline 24 & 317.1 & 339.7 & 318.6 & 296.9 & 54 & 2182 & 2378.5 & 2224.9 & 1951.2 \\
\hline 26 & 383.6 & 411.7 & 386.0 & 357.6 & 56 & 2379. & 2595.5 & 2427.5 & 2123.1 \\
\hline 28 & 457.6 & 491.8 & 461.0 & 424.7 & 58 & 2586. & 2823.5 & 2640.5 & 2303.3 \\
\hline 30 & 539.2 & 580.4 & 543.9 & 498.5 & 60 & 2803. & 3062.8 & 2864.0 & 2491.9 \\
\hline 32 & 628.6 & 677.6 & 634.9 & 579.1 & 62 & 3030. & 3313.6 & 3098.1 & 2689.0 \\
\hline 34 & 726.1 & 783.7 & 734.2 & 666.6 & 64 & 3268 . & 3575.9 & 3343.0 & 2894.7 \\
\hline
\end{tabular}


Ek Tablo 2. Kızılçam Çift Girişli Kabuklu Gövde Hacmi Tablosu

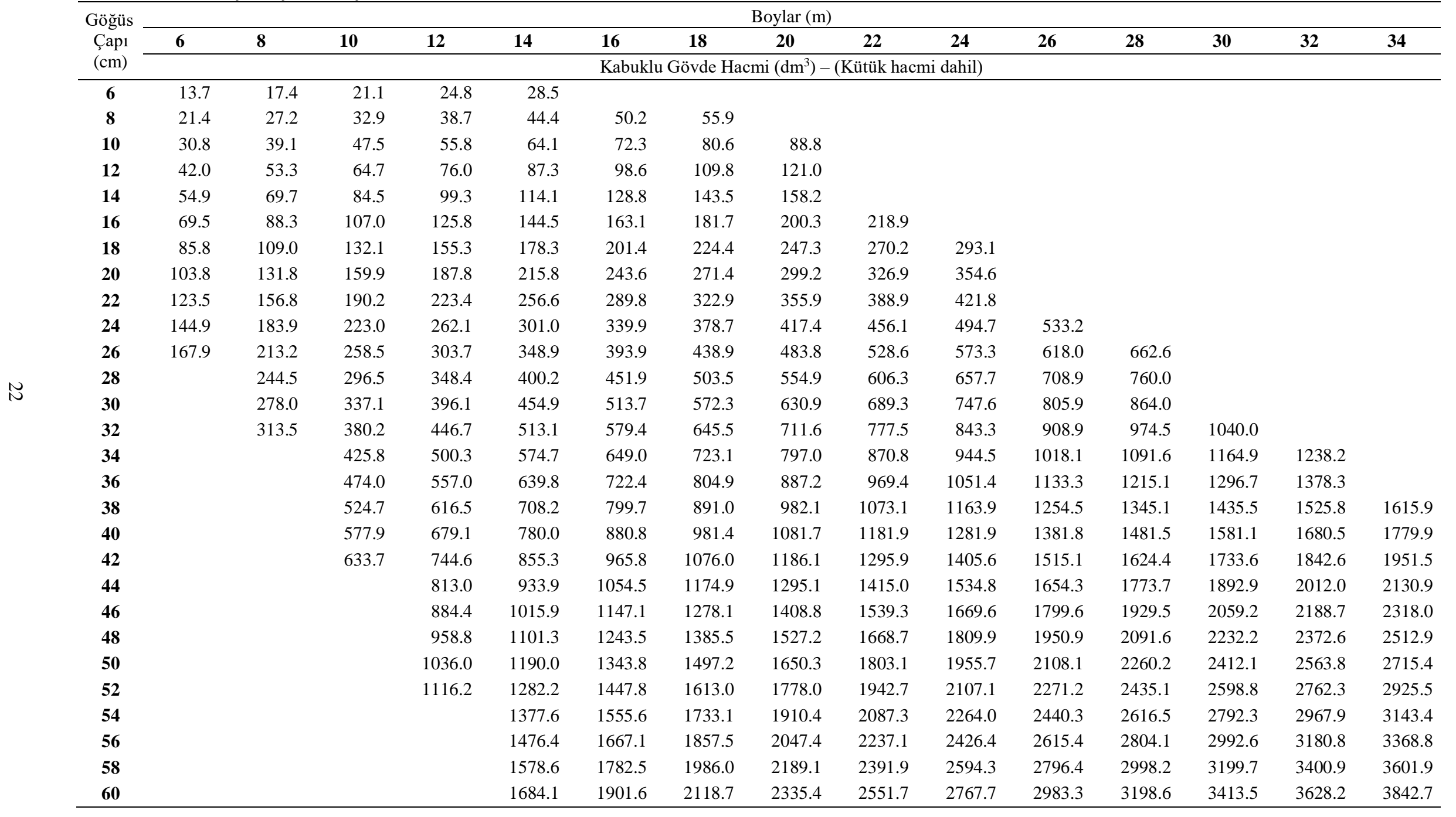

